\title{
Trypsin-like activity of membrane-bound midgut proteases from Anticarsia gemmatalis (Lepidoptera: Noctuidae)
}

\author{
Luciana Pereira XaVier ${ }^{1}$, Maria Goreti Almeida Oliveira $^{1,2 *}$, Raul Narciso Carvalho GUEDES ${ }^{2}$, Agenor $^{2}$ \\ VALAdAREs SANTOS ${ }^{3}$ and SAlvatore Giovanni DE SIMONE ${ }^{4}$ \\ ${ }^{1}$ Departament of Biochemistry and Molecular Biology, Institute of Biotechnology Applied to Agriculture and Animal Science \\ (BIOAGRO), Federal University of Viçosa, Viçosa, MG 36571-000, Brazil \\ ${ }^{2}$ Departament of Animal Biology, Federal University of Viçosa, Viçosa, MG 36571-000, Brazil \\ ${ }^{3}$ Departament of Microbiology, Institute of Biotechnology Applied to Agriculture and Animal Science (BIOAGRO), Federal \\ University of Viçosa, Viçosa, MG 36571-000, Brazil \\ ${ }^{4}$ Departament of Biochemistry and Molecular Biology, Foundation Oswaldo Cruz Institute (FIOCRUZ), Rio de Janeiro, RJ \\ 21045-900, Brazil
}

Keywords. Trypsin, proteases, velvetbean caterpillar, Lepidoptera, Noctuidae, Anticarsia

\begin{abstract}
Membrane-bound proteases from preparations of the midgut of $5^{\text {th }}$ instar velvetbean caterpillars, Anticarsia gemmatalis (Hübner) were obtained by resuspension of the pellet obtained after 100,000 $\mathrm{g}$ centrifugation. As expected of trypsin-like proteases, they hydrolyzed casein and the synthetic substrates $N$ - $\alpha$-benzoyl-L-Arg-p-nitroanilidine (L-BApNA) and $N$ - $\alpha$-p-tosyl-L-Arg methyl ester (L-TAME). Higher activities were observed at $50^{\circ} \mathrm{C}$, and at $\mathrm{pH} 8.5$ and 8.0 for both synthetic substrates L-BApNA and L-TAME. The membrane-bound proteases were inhibited by EDTA, phenylmethan sulphonyl fluoride (PMSF), tosyl-L-lysine chloromethyl ketone (TLCK), benzamidine and aprotinin. TLCK and benzamidine were particularly active inhibitors. The $\mathrm{K}_{\mathrm{M}}$-values obtained were $0.23 \mathrm{mM}$ for L-BApNA and $92.5 \mu \mathrm{M}$ for L-TAME. These results provide evidence for the presence of membranebound trypsin-like proteases in the midgut of the velvetbean caterpillar, a key soybean pest in warm climates. The interaction between A gemmatalis digestive proteases and soybean protease inhibitors has potentially important consequences for soybean breeding programs.
\end{abstract}

\section{INTRODUCTION}

An understanding of insect-plant interactions is important for predicting host plant colonization by insect-pests and for developing alternative control methods (Pedigo, 1989; Boulter, 1993; Bernays \& Chapman, 1994; Carlini \& Grossi-de-Sá, 2002). Plants usually contain an array of proteins toxic to insects, particularly the legumes that are rich in nitrogen (Bernays \& Chapman, 1994; Koiwa et al., 1997; Hilder \& Boulter, 1999; Stotz et al., 1999; Carlini \& Grossi-de-Sá, 2002). Arcelin, lectin, $\alpha$-amylase and protease inhibitors make up some of the nitrogen-rich defensive compounds present in legumes (Ryan, 1990; Felton \& Gatehouse, 1996; Jongsma \& Bolter, 1997; Koiwa et al., 1997; Stotz et al., 1999; Carlini \& Grosside-Sá, 2002).

Earlier reports on plant proteins active against insect proteases led to investigations of the interactions between insect digestive proteases and plant protease inhibitors, which have consequences for biotechnology and plant breeding (Hilder et al., 1987; Boulter, 1993; Hilder \& Boulter, 1999; Carlini \& Grossi-de-Sá, 2002). Serine proteases are the best-studied proteases and are present in viruses, prokaryotes and eukaryotes, suggesting they are vital for the survival of organisms. They are also frequently recorded in insects, particularly Lepidoptera, where they are the main family of proteases (Terra \& Ferreira, 1994). The most frequently studied serine proteases, trypsin- and chymotrypsin-like, act in a wide range of physiological processes including digestion, protein activation in the melanization cascade, antibacterial activity and insect immune response (Nakajima et al., 1997; Gorman et al., 2000a,b; Ma \& Kanost, 2000).

Trypsin-like enzymes preferentially cleave internal peptide bonds on the carboxyl side of basic L-amino acids, such as arginine and lysine, and are irreversibly inhibited by $\mathrm{N}-\alpha$-tosyl-L-lysine chloromethyl ketone (TLCK). The digestive activity of trypsin-like enzymes from insect midgut were studied and characterized in Auchenorrhyncha (Foissac et al., 2002), Blattodea (Elpidina et al., 2001; Marana et al., 2002; Lopes \& Terra, 2003), Coleoptera (Zhu \& Baker, 1999; Wagner et al., 2002), Diptera (Gorman \& Paskewitz, 2001; Muharsini et al., 2001) and Lepidoptera (Lee \& Anstee, 1995; Valaitis, 1995; Novillo et al., 1999).

In Lepidoptera, it is reported that the soluble trypsins found in secretory vesicles are derived from membranebound trypsins (Eguchi \& Iwamoto, 1976; Eguchi et al., 1982; Santos \& Terra, 1984; Santos et al., 1986). Jordão et al. (1999) suggest that the trypsin from Spodoptera frugiperda (Lepidoptera: Noctuidae) is probably processed

\footnotetext{
* Corresponding author: Departamento de Bioquímica e Biologia Molecular, Universidade Federal de Viçosa, Viçosa, MG 36571 000, Brasil; e-mail: malmeida@ufv.br
} 
by the Golgi complex and transported in secretory vesicles. These vesicles migrate through the cell microvilli merging with the apical membrane and are released in the larvae lumen. The present study provides evidence of the presence of membrane-bound trypsin-like proteases in midgut preparations of the velvetbean caterpillar, a key soybean pest in warm climates, and the likely occurrence of members of other protease families. The interaction between $A$. gemmatalis digestive proteases and protease inhibitors has potentially important consequences for soybean breeding programs.

\section{MATERIAL AND METHODS}

\section{Insects and chemicals}

Anticarsia gemmatalis was reared on the artificial diet described by Hoffman-Campo et al. (1985) and maintained under controlled conditions of $25 \pm 5^{\circ} \mathrm{C}, 70 \pm 10 \%$ r.h. and $14 \mathrm{~L}$ : 10D photoperiod. Fourth and fifth instar larvae were used in the experiments. All reagents were purchased from SigmaAldrich Brasil Ltda (São Paulo, SP, Brazil).

\section{Preparation of midgut extract}

Larvae were rinsed with water, chilled on ice and dissected in $10^{-3} \mathrm{M} \mathrm{HCl}$ at $4^{\circ} \mathrm{C}$. One hundred midguts (with contents) were subjected to nine cycles of nitrogen freezing and thawing at $37^{\circ} \mathrm{C}$ in a water bath. Aliquots of $1 \mathrm{ml}$ of midgut extract were centrifuged at $100,000 \mathrm{~g}$ for $45 \mathrm{~min}$ at $4^{\circ} \mathrm{C}$ and the pellets that formed resuspended in $10^{-3} \mathrm{M} \mathrm{HCl}$ with $0.5 \%$ Triton X-100 for $2 \mathrm{~h}$ at $4^{\circ} \mathrm{C}$. Another $100,000 \mathrm{~g}$ centrifugation for $30 \mathrm{~min}$ at $4^{\circ} \mathrm{C}$ followed. The resulting supernatant was stored at $-18^{\circ} \mathrm{C}$ and later used as an enzyme source after dialysis against 100 volumes of 0.1 M Tris-HCl buffer ( $\mathrm{pH} 8.5$ ).

\section{Protein assays}

Protein concentration was measured following Bradford (1976). Solutions of $0-0.2 \mathrm{mg} / \mathrm{ml}$ of bovine serum albumin (BSA) were used as standards.

\section{Enzyme assays}

Proteolytic activity was determined using casein as a substrate and monitored at a wavelength of $280 \mathrm{~nm}$ as described by Kunitz (1947) and adapted by Oliveira et al. (1993). Amidolytic activity was determined using $N$ - $\alpha$-benzoyl-L-Arg-pnitroanilidine (L-BApNA; $0.5 \mathrm{mM}$ ) as a substrate. For the determination of esterolytic activity $N$ - $\alpha$-p-tosyl-L-Arg methyl ester (L-TAME; $0.10 \mathrm{mM}$ ) was used (Hummel, 1959). Optimum $\mathrm{pH}$ conditions for enzyme activity were determined at $25^{\circ} \mathrm{C}$ using L-BApNA and L-TAME as substrates. These substrates were also used at temperatures varying from 15 to $65^{\circ} \mathrm{C}$ to assess the effect of temperature on enzyme activity. Three replicates were always used to quantify enzyme activity.

\section{Effect of calcium and protease inhibitors}

Calcium chloride $\left(\mathrm{CaCl}_{2}\right)$ was added to $0.5 \mathrm{mM}$ L-BApNA $\left(25^{\circ} \mathrm{C}\right)$ in $0.1 \mathrm{M}$ Tris- $\mathrm{HCl}(\mathrm{pH} 8.5)$ at final concentrations varying from 0 to $30 \mathrm{mM}$ to assess the effect of $\mathrm{Ca}^{++}$on enzyme activity. The same substrate and buffer system was used to test the effect of the following protease inhibitors on protease activity: ethylenediamine-tetracetic acid (EDTA; 0-100 mM), phenylmethan sulphonyl fluoride (PMSF; 0.04-3.20 $\mathrm{mM}$ ), tosyl-L-lysine chloromethyl ketone (TLCK; 0.005-1.0 mM), benzamidine $(0.001-1.0 \mathrm{mM})$ and aprotinin $(0.05-4.0 \mathrm{mM})$. Enzyme samples were incubated for $25 \mathrm{~min}$ with each protease inhibitor prior to the addition of L-BApNA to the mixture, which was then incubated for $2.5 \mathrm{~min}$ and the amidolytic activity determined as previously described.

\section{Kinetic assays}

The determination of the kinetic parameters $\mathrm{K}_{\mathrm{M}}$ and $\mathrm{V}_{\max }$ was carried out in $0.1 \mathrm{M}$ Tris- $\mathrm{HCl}$ (pH 8.5) with L-BApNA concentrations ranging from 0.019 to $1.2 \mathrm{mM}$. The kinetic parameters were determined for L-TAME at concentrations ranging from 0.013 to $0.8 \mathrm{mM}$ in $0.1 \mathrm{M}$ Tris- $\mathrm{HCl}(\mathrm{pH} 8.0)$ by non-linear regression using the software Enzfitter (Elsevier, Biosoft).

\section{RESULTS}

\section{Proteolytic activity and trypsin-like properties}

The proteolytic activity, detected with casein, followed the hyperbolic model of Michaelis-Menten (Fig. 1). Trypsin substrates are proteins, peptides and synthetic amides as well as esters with amides or ester bonds in their structures formed by the carboxyl groups of lysyl and arginyl basic residues (Neurath \& Schwert, 1950). Therefore two synthetic substrates, the amide L-BApNA and the ester L-TAME, were used to recognize the presence of trypsin-like proteases in the midgut epithelium of A. gemmatalis.

The temperature profile of protease activity, using L-BApNA as a substrate, showed three peaks, at temperatures 35,50 and $60^{\circ} \mathrm{C}$, with the highest activity at $50^{\circ} \mathrm{C}$ (Fig. 2A). The existence of more than one peak of activity suggests the presence of different forms of proteases in the microsomal fraction of the midgut homogenate of $A$. gemmatalis. When L-TAME was used as a substrate, only one peak of protease activity was observed at $50^{\circ} \mathrm{C}$ (Fig. 3A). The different peaks of activity observed with these two substrates is not surprising since L-TAME is a specific substrate for serine proteases, unlike L-BApNA, which is a substrate for serine and cysteine proteases. Therefore, the activity associated with these substrates is probably affected by non trypsin-like proteases, as reported in other Lepidoptera (Terra \& Ferreira, 1994; Valaitis, 1995; Jongsma \& Bolter, 1997).

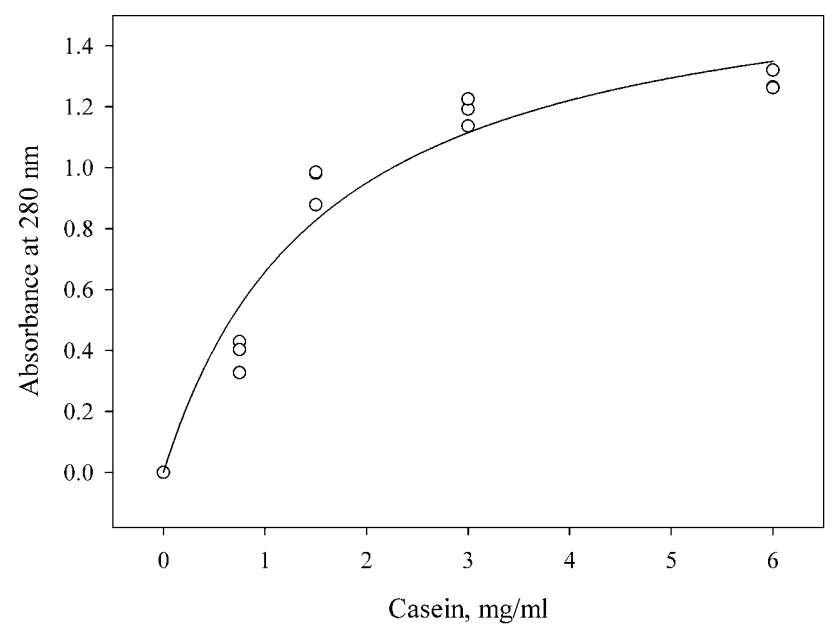

Fig. 1. Casein hydrolysis by membrane-bound midgut proteases of A. gemmatalis. Casein concentrations varied from 0.075 to $0.6 \%(\mathrm{w} / \mathrm{v})$. 

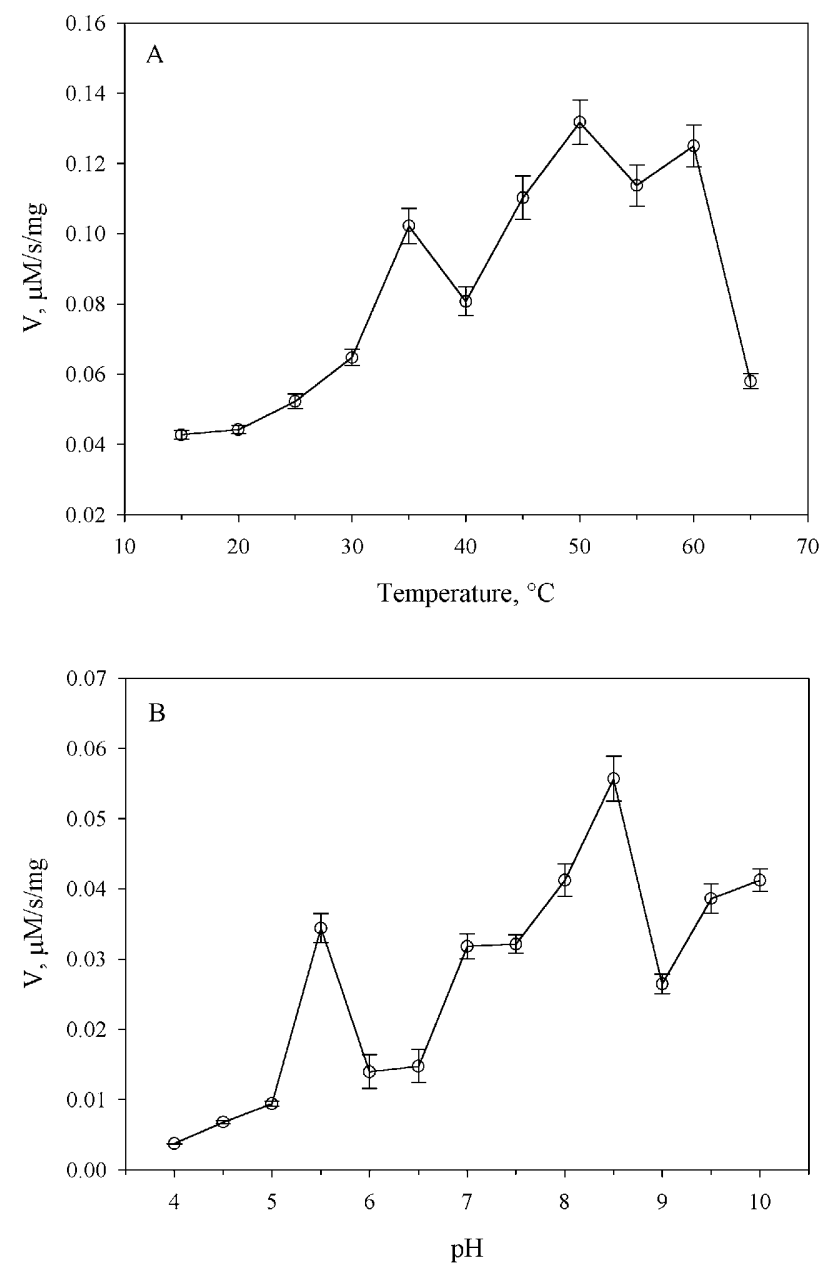

Fig. 2. Effect of temperature (A) and $\mathrm{pH}$ (B) on the membrane-bound protease activity of A. gemmatalis midgut using L-BApNA as a substrate. Each symbol represents the mean of three replicates $(n=3)$. Vertical bars indicate standard errors of the means.

Highest activity of membrane-bound proteases from $A$. gemmatalis midgut were observed at $\mathrm{pH} 5.5$ and 8.0 (highest) when L-BApNA was used as a substrate (Fig. 2B) providing support for the presence of two distinct trypsin-like enzymes. Only one peak at $\mathrm{pH} 8.0$ was observed in the activity profile of the insect proteases using L-TAME as a substrate (Fig. 3B). Increased protease activity was observed when $20 \mathrm{mM} \mathrm{Ca} \mathrm{Cl}$ (Fig. 4) was used, which accords with an earlier report that $\mathrm{Ca}^{++}$ stabilize bovine trypsin against autolysis at this concentration (Dias \& Rogana, 1986).
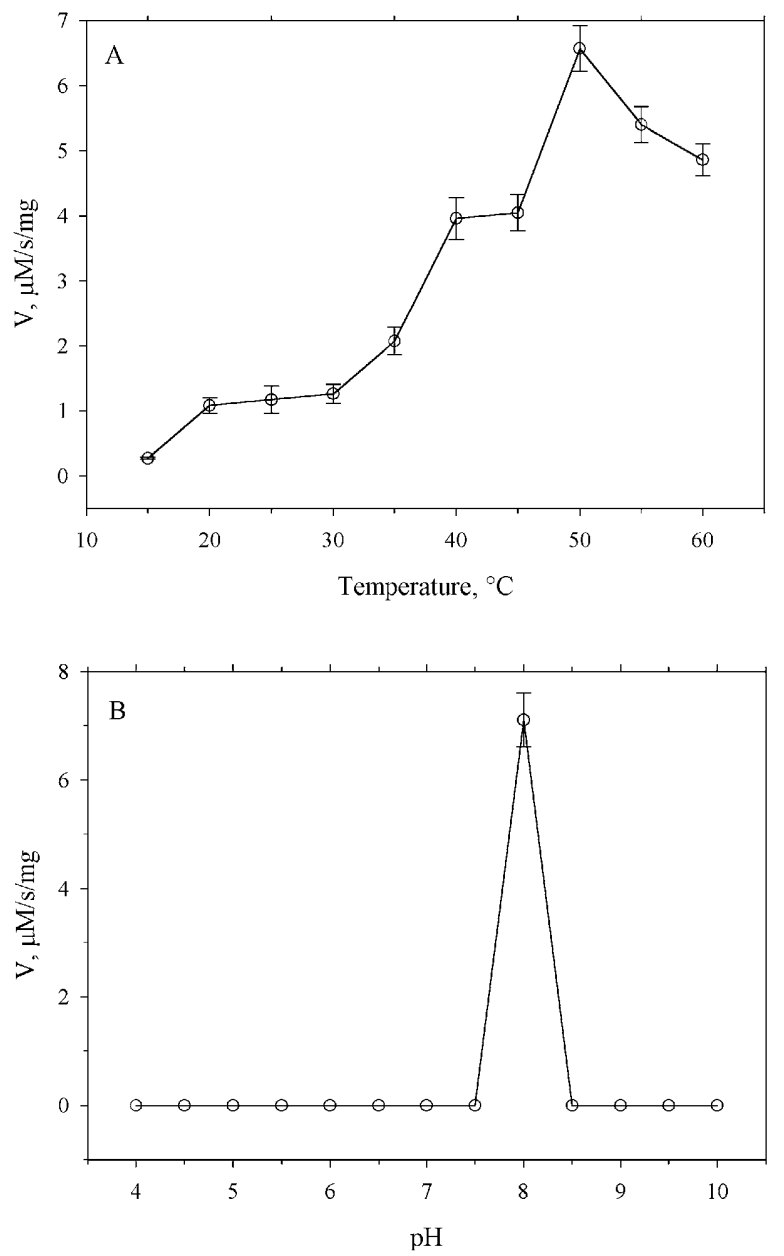

Fig. 3. Effect of temperature (A) and $\mathrm{pH}$ (B) on the membrane-bound protease activity of A. gemmatalis midgut using L-TAME as a substrate. Each symbol represents the mean of three replicates $(n=3)$. Vertical bars indicate standard errors of the means.

\section{Inhibition studies}

Trypsin-like activity of the membrane-bound proteases from $A$. gemmatalis was further characterized by the use of specific inhibitors in concentration-inhibition bioassays. The established curves followed the probit model (low $\chi^{2}$ and $p>0.05$ ), which allowed the $\mathrm{I}_{50}$ values to be estimated (i.e., inhibitor concentration required to achieve $50 \%$ inhibition of the protease activity) (Table 1 ). The metallo-protease inhibitor EDTA, which also inhibits proteases with metals as activity modulators, decreased the membrane-bound protease activity of $A$. gemmatalis

TABLE 1. Relative inhibition of membrane-bound proteases from A. gemmatalis, by five protease inhibitors.

\begin{tabular}{lcccc}
\hline Inhibitor & $\mathrm{I}_{50}(95 \% \mathrm{CL})$ & Degrees of freedom & $\chi^{2}$ & Probability $(p)$ \\
\hline EDTA & $89.77(71.43-136.30) \mathrm{mM}$ & 2 & 4.58 & 0.10 \\
PMSF & $0.63(0.48-0.91) \mathrm{mM}$ & 2 & 2.89 & 0.23 \\
TLCK & $39.24(23.59-60.63) \mu \mathrm{M}$ & 2 & 0.19 & 0.91 \\
Aprotinin & $11.27(6.23-42.84) \mu \mathrm{M}$ & 2 & 0.88 & 0.64 \\
Benzamidine & $475.13(245.15-1181.00) \mu \mathrm{M}$ & 2 & 4.37 & 0.11 \\
\hline
\end{tabular}




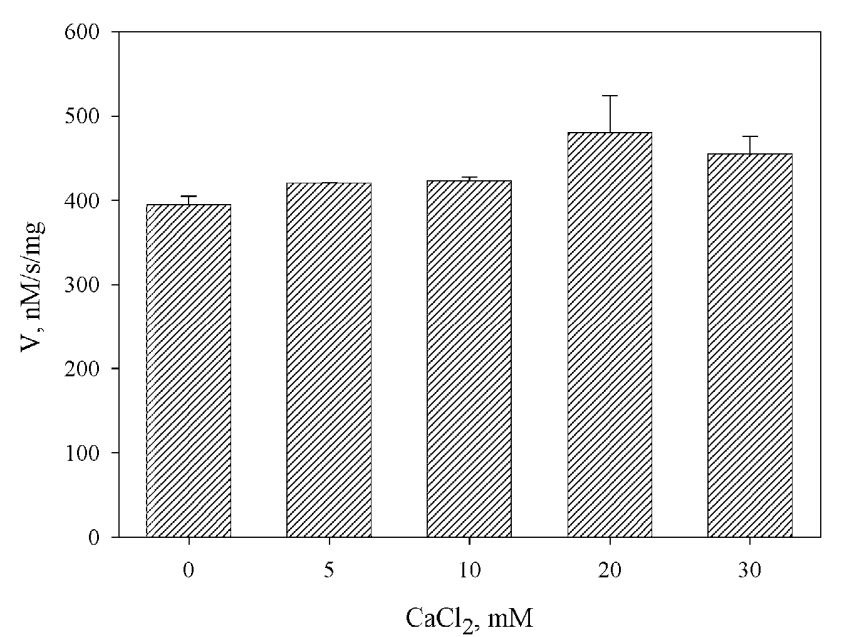

Fig. 4. Effect of $\mathrm{Ca}^{++}$on the membrane-bound protease specific activity of $A$. gemmatalis midgut using L-BApNA as a substrate. Each bar represents the mean of three replicates $(\mathrm{n}=$ $3)$. Vertical bars indicate standard errors of the means.

(Table 1). Similar findings reported for trypsin-like proteases from $S$. littoralis and Melolontha melolontha (Coleoptera: Scarabaeidae) lead to the suggestion that $\mathrm{Ca}^{++}$are involved in enzyme function (Lee \& Anstee, 1995; Wagner et al., 2002).

PMSF is a serine protease inhibitor that reacts with a serine residue in the reactive site of the enzyme (Barret, 1994). It inhibits serine-proteases, such as trypsin and trypsin-like enzymes, and in the present study inhibited membrane-bound proteases from A. gemmatalis (Table 1). TLCK, an irreversible inhibitor of trypsin-like serine proteases, alkylates an histidine residue close to the reactive serine of trypsins (Shaw et al., 1965). The membrane-bound proteases of $A$. gemmatalis were inactivated not only by PMSF, but also by TLCK (Table 1) that inhibits trypsins (Bernardi et al., 1996; Gatehouse et al., 1999; Novillo et al., 1999; Zhu \& Baker, 1999; Lam et al., 2000).

Aprotinin is a small peptide $(6.5 \mathrm{KDa})$ that strongly inhibits trypsin-like enzymes by tightly binding its $\operatorname{Arg}_{17}$ residue close to the active site of the enzyme (Röhlmann et al., 1973; Geiger \& Fritz, 1981; Oliveira et al., 1993). Aprotinin was preferred to soybean trypsin inhibitor (SBTI) as it is more frequently used for recognizing such enzymes (Röhlmann et al., 1973; Oliveira et al., 1993), what was the main objective of the present work. Membrane-bound midgut proteases of A. gemmatalis were significantly inhibited by aprotinin with an $\mathrm{I}_{50}$ of $11.22 \mu \mathrm{M}$ (Table 1), as expected for trypsin-like proteases and observed in Ostrinia nubilalis and S. littoralis (Bernardi et al., 1996; Marchetti et al., 1998). The synthetic trypsin inhibitor benzamidine (Mares-Guia et al., 1981) also inhibited the activity of the membrane-bound proteases of $A$. gemmatalis (Table 1) further confirming their trypsin-like nature, as in other species (Bernardi et al., 1996; Novillo et al., 1999; Zhu \& Baker, 1999; Lam et al., 2000).
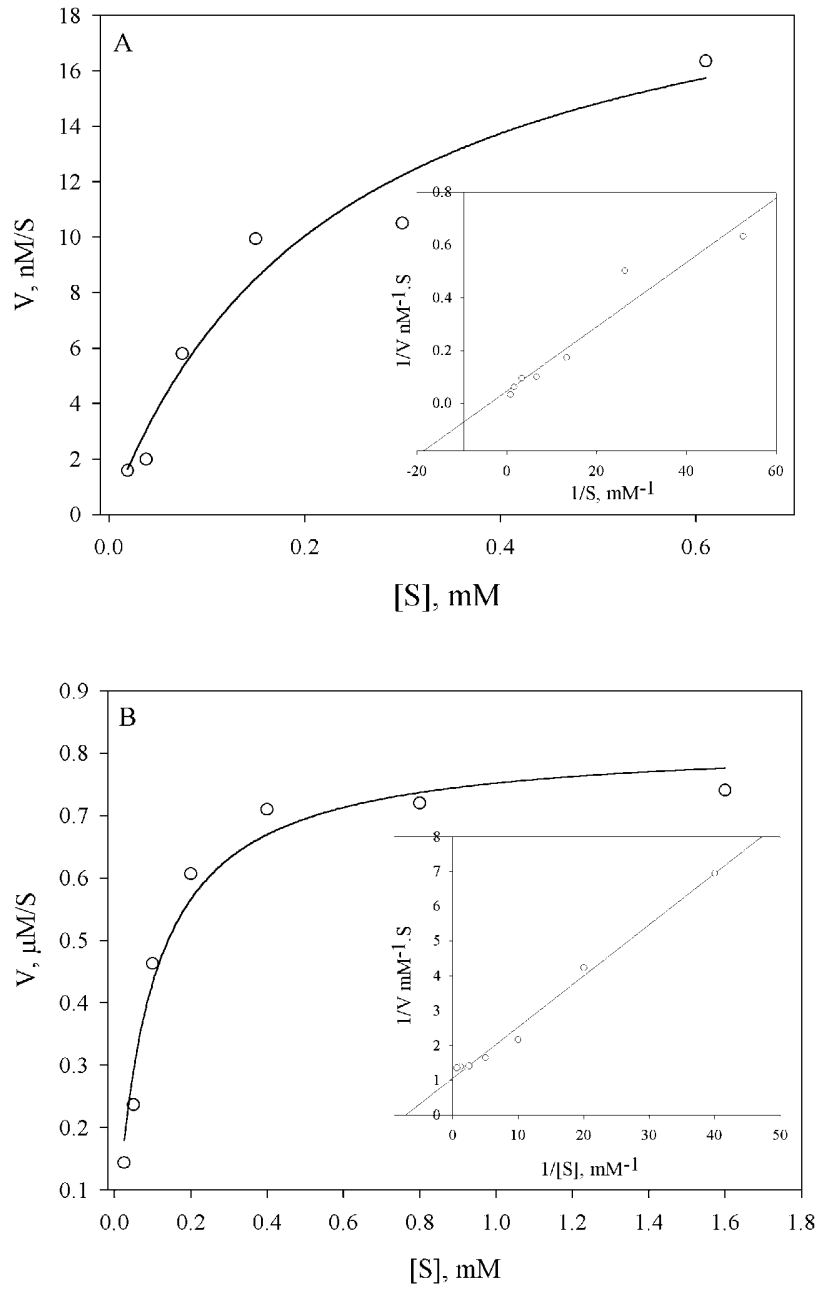

Fig. 5. Michaelis-Menten plot of the membrane-bound trypsin-like protease activity of $A$. gemmatalis midgut using L-BApNA (A) and L-TAME (B) as substrates. Insertion: Lineweaver-Burk plot (double reciprocal). Each symbol represents the mean of three replicates $(n=3)$.

\section{Kinetic studies}

The kinetic parameters of the membrane-bound midgut proteases of $A$. gemmatalis estimated using amide and ester synthetic substrates are given in Table 1. Over the range of substrate concentrations used both amidolytic and esterolytic activity showed the concentration-velocity curve with hyperbolic profile following the MichaelisMenten kinetic model (Fig. 5). The membrane-bound midgut proteases of $A$. gemmatalis had $\mathrm{K}_{\mathrm{M}}$ values of 0.23 $\mathrm{mM}$ in the L-BApNA and $95.4 \mu \mathrm{M}$ in the L-TAME hydrolyses (Table 2).

TABLE 2. Kinetic parameters of the membrane-bound trypsinlike proteases of $A$. gemmatalis.

\begin{tabular}{ccc}
\hline Substrate & $\mathrm{K}_{\mathrm{M}}$ & $\mathrm{V}_{\max }$ \\
L-BApNA & $0.23 \mathrm{mM}$ & $21.8 \mathrm{nM} / \mathrm{s}$ \\
L-TAME & $95.4 \mu \mathrm{M}$ & $0.82 \mu \mathrm{M} / \mathrm{s}$ \\
\hline
\end{tabular}




\section{DISCUSSION}

In insects, the processing of precursors and the secretory mechanism of digestive enzymes differ from that found in other animals (Terra \& Ferreira, 1994). This study of the process is therefore an important contribution to cell biology and may provide new targets for alternative control methods. The first study of the mechanism of enzyme secretion in Lepidoptera was done using larvae of Bombyx mori and indicated that membrane-bound trypsin-like proteases are transported from the tissues to the lumen of the gut where they are solubilized and converted into an active form. Some of the trypsin-like proteases are incorporated in the peritrophic membrane, an extracellular sheath which protects the midgut epithelial cells (Eguchi et al., 1982; Kuriyama \& Eguchi, 1985).

Enzymes are bound in cell membranes by means of a hydrophobic peptide or a GPI-anchor. Enzymes bound by hydrophobic peptides are usually solubilized by high (e.g., octylglucoside, CHAPS) or low (e.g., Triton X-100) CMC (critical micellar concentration) detergents and are at least partially released from membranes by the action of papain or trypsin (Hooper \& Turner, 1988). Enzymes anchored via GPI are released into solution by high CMC detergents or by GPI-PLC treatment (Hooper \& Turner, 1988). Trypsins were found in fractions of ectoperitrophic fluid obtained by differential centrifugation (Ferreira et al., 1994). The detection of proteolytic activity in the insoluble fraction from the midgut of $A$. gemmatalis, after treatment with Triton X-100 and centrifugation at $100,000 \mathrm{~g}$, indicates the occurrence of membrane-bound proteases that may be at least partially transferred to the peritrophic membrane.

The membrane-bound digestive proteases of $A$. gemmatalis hydrolyzed both protein and synthetic substrates. The protein hydrolytic activity was assessed using casein as a substrate, which showed a similar kinetic profile to those obtained using the synthetic substrates L-BApNA and L-TAME. Activity towards these substrates was expected of trypsin-like proteases and was observed for the membrane-bound proteases from $A$. gemmatalis. The activity profiles obtained using these substrates differed, which suggests the presence of other proteases, probably cysteine proteases, since L-BApNA is also a substrate for this family of enzymes.

EDTA decreased the membrane-bound activity of $A$. gemmatalis midgut proteases, probably by sequestering $\mathrm{Ca}^{++}$associated with the amino acid residues of the protein structure. At least some insect trypsin-like proteases are likely to have $\mathrm{Ca}^{++}$as a co-factor (Houseman et al., 1989; Wagner et al., 2002), as may be the case for $A$. gemmatalis, where $\mathrm{Ca}^{++}$positively modulate membranebound trypsin-like activity in the midgut. These results, however, contrast with those from other insect trypsins, which are unaffected by $\mathrm{Ca}^{++}$(Lewinsky et al., 1977; Johnston et al., 1991; Lemos \& Terra, 1992).

The serine protease competitive inhibitor PMSF also inhibited the membrane-bound protease activity of $A$. gemmatalis. TLCK, a trypsin inhibitor, decreased L-BApNA hydrolysis in the present study probably by alkylating the histidine residue of the catalytic triade of these enzymes (Shaw et al., 1965). These results indicate that serine proteases or, more particularly, trypsin-like serine proteases are present as membrane-bound proteases, since they are inhibited by PMSF and TLCK. The stronger inhibition provided by TLCK, a specific trypsinlike inhibitor, than PMSF, a serine protease inhibitor, indicates the occurrence of other serine proteases in the velvetbean caterpillar and protease enzymes, probably cysteine protease, as also previously indicated by the activity profiles of L-BApNA and L-TAME. In addition, $\mathrm{Ca}^{++}$seem to be a co-factor positively modulating the trypsin-like activity, which is inhibited by EDTA. Aprotinin and benzamidine, two well-known trypsin inhibitors (Mares-Guia \& Shaw, 1965; Mares-Guia, 1968; MaresGuia et al., 1981; Bernardi et al., 1996), also inhibited the activity of the membrane bound proteases of $A$. gemmatalis and provide further support for their being trypsinlike serine proteases.

Inhibition of mammalian and insect proteases may differ indicating that the disruption of insect protein digestion when fed on transformed plants containing protease inhibitors requires the prior selection of the appropriate inhibitors for the digestive proteases of the insect pest species to be targeted (Reeck et al., 1997). Protease activity in $A$. gemmatalis was inhibited by aprotinin (the bovine pancreatic trypsin inhibitor, BPTI), which may be useful for transferring the soybean genome aimed at insect resistance. Nevertheless, validation by characterizing A. gemmatalis soluble midgut proteases and subsequent feeding trials are needed before attempting crop transformation. In addition, insect resistance to plant protease inhibitors has been reported in several species of insect (Broadway, 1995; Jongsma \& Bolter, 1997) and therefore an understanding of the mechanism by which the velvetbean caterpillar enzyme couple with soybean protease inhibitors will aid the selection of inhibitors that will prevent or delay the development of resistance.

The $\mathrm{K}_{\mathrm{M}}$ value for L-BApNA hydrolysis was $2.4 \times$ higher than that for L-TAME. Therefore the membranebound trypsin-like proteases of $A$. gemmatalis show a better binding to L-TAME than to L-BApNA, as reported for bovine trypsin (Nakata \& Ishii, 1972; MagalhãesRocha et al., 1980). This higher efficiency against the ester substrate may be due to the reaction mechanism catalyzed by serine proteases. These enzymes show a slow acylation during their amidolytic activity followed by fast deacylation for product formation; the opposite occurs during esterolytic activity (Inagami, 1972; Fastrez $\&$ Fersht, 1973). Therefore the rate-limiting step in amide hydrolysis by these trypsin-like enzymes is acylation, while in ester hydrolysis it is deacylation.

The induction of host plant protease inhibitors via the lipoxygenase (LOX) pathway is a defensive response to attack by insects and pathogens (Farmer \& Ryan, 1992). This response to insect injury can inhibit the activity of insect midgut proteases leading to an hyperproduction of proteolytic enzymes and reduced availability of essential amino acids for insect growth and development 
(Broadway \& Duffey, 1986; Broadway, 1995). Plantinduced protease inhibitors can inhibit insect midgut proteases leading to death and such a control method may be exploited in one of two ways against insect-pests like $A$. gemmatalis. First by applying peptides or mimetic peptides, which are potent inhibitors of insect midgut proteases, like insecticides. Secondly, by transforming the soybean genome for increased expression of a potent protease inhibitor. Future characterization of purified midgut proteases of $A$. gemmatalis and the assessment of their relevance in soybean- $A$. gemmatalis interactions will direct future efforts to develop more effective control methods.

ACKNOWLEDGEMENTS. The financial support provided by the CAPES Foundation, National Council of Scientific and Technological Development $(\mathrm{CNPq})$ and the Minas Gerais State Foundation for Research Aid (FAPEMIG) is greatly appreciated. The comments and suggestions provided by three anonymous referees are also greatly appreciated and acknowledged.

\section{REFERENCES}

BARRetT A.J. 1994: Classification of peptidases. Meth. Enzymol. 244: $1-5$.

Bernardi R., Tedeschi G., Ronchi S. \& Palmieri S. 1996: Isolation and some molecular properties of a tripsin-like from larvae of European corn borer Ostrinia nubilalis Hübner (Lepidoptera: Pyralidae). Insect Biochem. Mol. Biol. 26: 883-889.

Bernays E.A. \& Chapman R.F. 1994: Host-Plant Selection by Phytophagous Insects. Chapman \& Hall, NewYork, 312 pp.

Boulter D. 1993: Insect pest control by copying nature using genetically engineered crops. Phytochemistry 34: 1453-1466.

BRADFORD M.M. 1976: A rapid and sensitive method for the quantification of microgram quantities of proteins utilizing the principle of protein dye binding. Anal. Biochem. 72: 248-254.

BROADWAY R.M. 1995: Are insects resistant to plant proteinase inhibitors? J. Insect Physiol. 41: 107-116.

BroadwaY R.M. \& DufFeY S.S. 1986: Plant proteinase inhibitors: Mechanism of action and effect on the growth and digestive physiology of larval Heliothis zea and Spodoptera exigua. J. Insect Physiol. 32: 827-833.

Carlini C.R. \& Grossi-De-SÁ M.F. 2002: Plant toxic proteins with inseticidal properties. A review on their potentialities as bioinseticides. Toxicon 40: 1515-1539.

Dias C.L.F. \& Rogana E. 1986: Autolysis of $\beta$-trypsin at $\mathrm{pH}$ 3.0. Braz. J. Med. Biol. Res. 19: 11-18.

Eguchi M. \& Iшамото A. 1976: Alkaline proteases in midgut tissue and digestive fluid of the silkworm, Bombyx mori. Insect Biochem. 6: 491-496.

Eguchi M., Iwamoto A. \& Yamauchi K. 1982: Interrelation of proteases from the midgut lumen, epithelia and peritrophic membrane of the silkworm, Bombyx mori L. Comp. Biochem. Physiol. (A) 72: 359-363.

Elpidina E., Vinokurov K.S., Gromenko V.A., Rudenskaya Y.A., Dunaevsky Y.E. \& Zhuzhikov D.P. 2001: Compartmentalization of proteinases and amylases in Nauphoeta cinerea midgut. Arch. Insect Biochem. Physiol. 48: 206-216.

FARMER E.E. \& RYAN C.A. 1992: Octadecanoid precursors of jasmonic acid activate the syntesis of wound-inducible proteinase inhibitors. Plant Cell 4: 129-134.
Fastrez J. \& Fersht A.R. 1973: Demonstration of the acylenzyme mechanism for the hydrolysis of peptides and anilides by chymotrypsin. Biochemistry 12: 2025-2034.

Felton G.W. \& Gatehouse J.A. 1996: Antinutritive plant defence mechanisms. In Lehane M.J. \& Billingsley P.F. (eds): Biology of the Insect Midgut. The University Press, Cambridge, pp. 373-416.

Ferreira C., Capella A.N., Sitnik R. \& Terra W.R. 1994: Digestive enzymes in midgut cells, endo- and ectoperitrophic contents and peritrophic membranes of Spodoptera frugiperda (Lepidoptera) larvae. Arch. Insect Biochem. Physiol. 26: 299-313.

Foissac X., Edwards M., Du J.P., Gatehouse A.M.R. \& GateHouse J.A. 2002: Putative protein digestion in a sap-sucking homopteran plant pest (rice brown plant hopper; Nilaparva lugens: Delphacidae) - identification of trypsin-like and cathepsin B-like proteases. Insect Biochem. Mol. Biol. 32: 967-978.

Gatehouse A.M.R., Norton E., Davison G.M., Babbé S.M., Newell C.A. \& Gatehouse J.A. 1999: Digestive proteolytic activity in larvae of tomato moth, Lacanobia oleracea; effects of plant protease inhibitors in vitro and in vivo. $J$. Insect Physiol. 45: 545-558.

Geiger R. \& Fritz H. 1981: Human urinary kalicrein. In Loreland L. (ed): Proteolitic Enzymes: Part C. Academic Press, New York, pp. 466-492.

Gorman M.J. \& Paskewitz S.M. 2001: Serine proteases as mediators of mosquito immune response. Insect Biochem. Mol. Biol. 31: 257-262.

Gorman M.J., Andreeva O.V. \& Paskewitz S.M. 2000a: Molecular characterization of five serine protease genes cloned from Anopheles gambiae hemolymph Insect Biochem. Mol. Biol. 30: 35-46.

Gorman M.J., Andreeva O.V. \& Paskewitz S.M. 2000b: Sp22D: a multidomain serine protease with a putative role in insect immunity. Gene 251: 9-17.

HiLder V.A. \& Boulter D. 1999: Genetic engineering of crop plants for insect resistance - a critical review. Crop Prot. 18: 177-191.

Hilder V.A., Gatehouse A.M.R., Sheerman S.E., Barker R.F. \& BOULTER D. 1987: A novel mechanism of insect resistance engineered into tobacco. Nature 330: 160-163.

Hoffman-Campo C.B., Oliveira E.B. \& Moscardi F. 1985: Criação Massal de Lagarta-da-Soja (Anticarsia gemmatalis). EMBRAPA-CNPSo., Londrina, 23 pp.

HoOper N.M. \& TURNER A.J. 1988: Ectoenzymes of the kidney microvillar membrane. Differential solubilization by detergents can predict a glycosyl-phosphatidylinositol membrane anchor. Biochem. J. 250: 865-869.

Houseman J.G., Philogene B.J.R. \& Downe A.E.R. 1989: Partial characterization of proteinase activity in the larval gut of the European corn borer Ostrinia nubilalis Hübner (Lepidoptera: Pyralidae). Can. J. Zool. 67: 864-868.

Hummel B.C.W. 1959: A modified spectrophotometric determination of chymotrypsin, trypsin, and trombin. Can. J. Biochem. Physiol. 37: 1393-1399.

InaGami T. 1972: Trypsin. In Funatsu M., Hiromi K., Imahori K., Murachi T. \& Narita K. (eds): Proteins: Structure and Function. Kodanskap, Tokyo, pp. 1-83.

Johnston K.A., Gatehouse J.A. \& Anstee J.H. 1991: The partial purification and characterization of serine protease activity in midgut of larval Helicoverpa armigera. Insect Biochem. 21: 389-397.

Jongsma M.A. \& Bolter C. 1997: The adaptation of insects to plant protease inhibitors. J. Insect Physiol. 43: 885-895. 
Jordão B.P., Capella A.N., Terra W.R., Ribeiro A.F. \& FerREIRA C. 1999: Nature of the anchors of membrane-bound aminopeptidase, amylase, and trypsin and mechanism in Spodoptera frugiperda (Lepidoptera) midgut cells. J. Insect Physiol. 45: 29-37.

Koiwa H., Bressan R.A. \& Hasegawa P.M. 1997: Regulation of protease inhibitors and plant defense. Trends Plant Sci. 2: 379-384.

KunITZ M. 1947: Crystalline soybean trypsin inhibitor. II - General properties. J. Gen. Physiol. 30: 291-310.

KuRIYAma K. \& Eguchi M. 1985: Conversion of the molecular form alkaline treatment of gut protease from the silkworm Bombyx mori. Comp. Biochem. Physiol. (B) 82: 575-579.

Lam W., Coast G.M. \& Rayne R.C. 2000: Characterization of multiple trypsins from the midgut of Locusta migratoria. Insect Biochem. Mol. Biol. 30: 85-94.

Lee M.J. \& Anstee J.H. 1995: Endoproteases from the midgut of larval Spodoptera littoralis includes a chymotrypsin-like enzyme with an extended binding site. Insect Biochem. Mol. Biol. 25: 49-61.

Lemos F.J.A. \& TerRa W.R. 1992: Soluble and membrane-bond forms of trypsin-like enzymes in Musca domestica larval midguts. Insect Biochem. Mol. Biol. 22: 613-619.

Lewinsky H., Birk Y. \& Applebaum S.W. 1977: Isolation and characterization of a new trypsin-like enzyme from Tenebrio molitor L. larvae. Int. J. Pept. Prot. Res. 10: 252-264.

Lopes A.R. \& Terra W.R. 2003: Purification, properties and substrate specificity of a digestive trypsin from Periplaneta americana (Dictyoptera) adults. Insect Biochem. Mol. Biol. 33: $407-415$.

Ma C.C. \& Kanost M.R. 2000: A beta 1,3-glucan recognition protein from an insect, Manduca sexta agglutinates microorganisms and activates the phenoloxidase cascade. J. Biol. Chem. 275: 7505-7514.

Magalhães-Rocha N.M., Rogana E. \& Mares-Guia M. 1980 Kinetic parameters for the activation of $\alpha$ and $\beta$-trypsin by the methyl ester of the tosyl-L-arginine (Tos-L-Arg-OMe). Arch. Biochem. Biophys. 200: 61-64.

Marana S.R., Lopes A.R., Juliano L., Juliano M.A., Ferreira C. \& TERRA W.R. 2002: Subsites of trypsin active site favor catalysis or substrate binding. Biochem. Biophys. Res. 290: 494-497.

Marchetti S., Chiaba C., Chiesa F., Bandiera A. \& Pitotti A. 1998: Isolation and partial characterization of two trypsins from the larval midgut of Spodoptera littoralis (Boisduval). Insect Biochem. Mol. Biol. 28: 449-458.

Mares-Guia M. 1968: Hydrophobic interactions in the trypsin active center. The sensitivity of the hydrophobic binding site to side chain modifications in competitive inhibitors of the amidinium type. Arch. Biochem. Biophys. 127: 317-322.

Mares-Guia M. \& SHAw E. 1965: Studies on the active center of trypsin. The binding of amidines and guanidines as models of the substrate side chain. J. Biol. Chem. 240: 1579-1585.

Mares-Guia M., Rogana E., Amorin A.F. \& Magalhães-Rocha N.M. 1981: Kinetic evidence for a two-state, hybrid model for the trypsin activation by modifiers. J. Biol. Chem. 256: 1661-1668.

Muharsini S., Dalrymple B., Vuocolo T., Hamilton S., WilLADSEN P. \& WiJfFels G. 2001: Biochemical and molecular characterization of serine proteases from larvae Chrysomya bezziana, the old screwworm fly. Insect Biochem. Mol. Biol. 31: 1029-1040.
Nakajima Y., Tsuji Y., Homma K. \& Natori S. 1997: A novel protease in the pupal yellow body of Sarcophaga peregrina (flesh fly). J. Biol. Chem. 272: 23805-23810.

NAKATA A. \& IshiI S.I. 1972: Substrate activation of trypsin and acethyl-trypsin caused by $N$-a-benzyl-L-arginine-p-nitroanilide. J. Biochem. 72: 281-290.

Neurath H. \& Schwert G.W. 1950: The mode of action of the crystalin pancreatic proteolytic enzimes. Chem. Rev. 46: 69-153.

Novillo C., Castañera P. \& Ortego F. 1999: Isolation and characterization of two digestive trypsin-like proteinases from larvae of the stalk corn borer, Sesamia nonagrioides. Insect Biochem. Mol. Biol. 29: 177-184.

Oliveira M.G.A., Rogana E., Rosa J.C., Reinhold B.B., Andrade M.H., GreEne L.J. \& Mares-Guia M. 1993: Tyrosine 151 is part of the substrate activation binding site. $J$. Biol. Chem. 268: 26893-26903.

Pedigo L.P. 1989: Entomology and Pest Management. Macmillan, New York, 646 pp.

Reeck G.R., Kramer K.J., Baker J.E., Kanost M.R., Fabrick J.A. \& BehnKe G.A. 1997: Proteinase inhibitors and resistance of transgenic plants to insects. The role of transgenic plants. In Carozzi N. \& Koziel M. (eds): Advances in Insect Control. Taylor and Francis, London, pp. 157-183.

Röhlmann A., Kukla D., Schwager P., Bartels K. \& Huber R. 1973: Structure of the complex formed by bovine trypsin and bovine pancreatic trypsin inhibitor. J. Biol. Chem. 77: 417-436.

Ryan C.A. 1990: Genes for improving defences against insects and pathogens. Annu. Rev. Phytopathol. 28: 245-449.

Santos C.D. \& Terra W.R. 1984: Plasma membrane-associated amylase and trypsin. Intracellular distribution of digestive enzymes in the midgut of the cassava hornworm, Erinnyis ello. Insect Biochem. 14: 587-594.

Santos C.D., Ribeiro A.F. \& Terra W.R. 1986: Differential centrifugation, calcium precipitation and ultrasonic disruption of midgut cells of Erinnyis ello caterpillars. Can. J. Zool. 64: 490-500.

Shaw E., Mares-Guia M. \& Cohen W. 1965: Evidence for an active-center hystidine in trypsin through use of a specific reagent 1-chloro-3-tosylamido-7-amino-2-heptanona, the chloromethyl ketone derived from $N$ - $\alpha$-tosyl-L-lysine. Biochemistry 4: 2219-2224.

Stotz H.U., Kroymann J. \& Mitchell-Olds T. 1999: Plantinsect interactions. Cur. Opinion Plant Biol. 2: 268-272.

TERra W.R. \& Ferreira C. 1994: Insect digestive enzymes: properties, compartmentalization and function. Comp. Biochem. Physiol. (B) 109: 1-62.

VALAitis A.P. 1995: Gypsy moth midgut proteinases: purification and characterization of luminal trypsin, elastase and the brush border membrane leucine aminopeptidase. Insect Biochem. Mol. Biol. 25: 139-149.

Wagner W., Möhrlen F. \& Schnetter W. 2002: Characterization of the proteolytic enzymes in the midgut of the European cockchafer, Melolontha melolontha (Coleoptera: Scarabaeidae). Insect Biochem. Mol. Biol. 32: 803-814.

ZHU Y.-C. \& BAKER J.E. 1999: Characterization of midgut trypsin-like enzyme and three trypsinogen cDNAs from the lesser grain borer, Rhyzopertha dominica (Coleoptera: Bostrichidae). Insect Biochem. Mol. Biol. 29: 1053-1063.

Received July 1, 2004; revised and accepted November 29, 2004 